Anatomy

\title{
Seed structure and in vitro seedling development of certain Laeliinae species (Orchidaceae)
}

\author{
Estructura de semillas y desarrollo de plántulas in vitro de ciertas especies de Laeliinae \\ (Orchidaceae)
}

\author{
Fabiana R. Gallo ${ }^{a}$, Luiz A. Souza ${ }^{a}, *$, Maria A. Milaneze-Gutierre ${ }^{a}$, Odair J.G. Almeida ${ }^{a}, b$ \\ a Departamento de Biologia, Universidade Estadual de Maringá, Avenida Colombo, 5790, CEP 87020-900 Maringá, Paraná, Brazil \\ ${ }^{\mathrm{b}}$ Universidade Estadual Paulista, Unidade do Litoral Paulista, 11330-900 São Vicente, SP, Brazil
}

Received 20 May 2014; accepted 17 September 2015

Available online 4 March 2016

\begin{abstract}
Seeds and seedlings of neotropical Laeliinae species (Cattleya loddigesii, Cattleya tigrina, Hadrolaelia purpurata, Laelia anceps, Schomburgkia gloriosa, and Sophronitis cernua) were studied. The seed germination process and the seedling grown in vitro are described. Seeds of the studied species are unitegmic and have conspicuous thickening in the anticlinal and inner periclinal cell walls. The embryo consists of a relatively long and multicellular suspensor. At first stage of seedling development, the embryo differentiates into a protocorm with rhizoids and meristematic tissue. The budding occurs on the protocorms. The endogenous taproot is produced after the first leaves have emerged. The root is triarch or tetrarch and it possesses velamen. Structural characters related to seed coat, suspensor, ontogeny of leaves, and vascular system of the root are significant indicators for the separation of Laeliinae species.

All Rights Reserved (C) 2016 Universidad Nacional Autónoma de México, Instituto de Biología. This is an open access item distributed under the Creative Commons CC License BY-NC-ND 4.0.

Keywords: Embryo; Leaf; Protocorm; Root; Seed coat

\section{Resumen}

En este trabajo se realizó un análisis comparativo de semillas y plántulas en especies neotropicales de la subtribu Laeliinae (Cattleya loddigesii, C. tigrina, Hadrolaelia purpurata, Laelia anceps, Schomburgkia gloriosa, y Sophronitis cernua). Se describe el proceso de germinación de semillas y el desarrollo de plántulas cultivadas in vitro. Las semillas presentan un tegumento con un engrosamiento visible en las paredes. El embrión tiene un suspensor multicelular alargado. En la primera etapa del desarrollo de la plántula, el embrión se transforma en un protocormo con rizoides y tejido meristemático en el que aparecen los brotes primordiales. La raíz primaria se produce después de las hojas, es de tipo triarca o tetrarca con velamen. En conclusión, las características estructurales asociadas con la cubierta seminal, el desarrollo ontogenético de la hoja y el sistema vascular de la raíz, son indicadores significativos para la identificación de las especies estudiadas de Laeliinae.

Derechos Reservados @ 2016 Universidad Nacional Autónoma de México, Instituto de Biología. Este es un artículo de acceso abierto distribuido bajo los términos de la Licencia Creative Commons CC BY-NC-ND 4.0.
\end{abstract}

Palabras clave: Embrión; Hoja; Protocormo; Raíz; Cubierta seminal

\footnotetext{
* Corresponding author.

E-mail address: lasouza@uem.br (L.A. Souza).

Peer Review under the responsibility of Universidad Nacional Autónoma de México.
}

\section{Introduction}

Laeliinae species (Orchidaceae) are strictly neotropical and comprise about 50 genera with 1,500 species (Dressler, 1981, 1993), it is the third largest subtribe in the family after the Pleurothallidinae and Oncidiinae (Van den Berg et al., 2009). Laeliinae species show high morphological diversity and great 
taxonomic divergence (Van den Berg et al., 2009). Dressler (1981) included in this subtribe the genera Cattleya Lindl., Laelia Lindl., Schomburgkia Lindl. and Sophronitis Lindl.; Van den Berg et al. $(2005,2009)$ in a broad phylogenetic analysis within Laeliinae, supported the inclusion of Schomburgkia and Sophronitis species in Laelia and Cattleya, respectively. For the present study of Laeliinae genera, we followed the system according to the List of Species of the Brazil Flora (Lista de espécies da Flora do Brasil, 2012).

Van den Berg et al. (2009) pointed out the main factors of diversification within Laeliinae remain a rich field for research, due to the great variation of morphological features, the large number of species, and generic and infrageneric groupings. In addition, both the seed, as well as the fruit structure have been neglected in the Orchidaceae (Dressler, 1993); Barthlott (1976) stated that seed structures are especially useful at the tribal and subtribal levels.

Reproductive structures of orchids have wide morphogenetic potential, conditioned by the high totipotency of their cells which contributes to a complex reproductive system (Batygina, Bragina, \& Vasileyeva, 2003). Furthermore, those authors pointed out that data set, the advance of theoretical knowledge on reproductive structures, and the methods of plant micropropagation may be useful for conservation programs, in addition to benefit the introduction of secondary populations under natural conditions.

In this scope, a comparative study of seed structure in 6 species of Laeliinae orchids: Cattleya loddigesii Lindl., Cattleya tigrina A.Rich, Hadrolaelia purpurata (Lindl.) Chiron \& V.P.Castro, Laelia anceps Lindl., Schomburgkia gloriosa Rchb. and Sophronitis cernua Lindl. was accomplished. Furthermore, additional observations on the seedling anatomy were performed for $H$. purpurata, S. gloriosa and S. cernua. This study contributes to the structural knowledge of this group of flowering plants, which can be useful for future taxonomic treatments for Laeliinae orchids and may help to clarify the nature and structural relations about the seedling organs.

\section{Materials and methods}

Seeds from 6 species of orchids (C. loddigesii, $C$. tigrina, H. purpurata, L. anceps, S. gloriosa and S. cernua) from different origins were sterilized by soaking in $15 \%$ sodium hypochlorite solution $(\mathrm{NaClO})$. In order to assure seed viability, samples were analyzed through the tetrazolium test for seed viability, using 2,3,5 triphenyl tetrazolium - 1\% solution (Singh,
1981). Only seeds that achieved at least $50 \%$ of viability were selected for the study.

The viable seeds were placed on a sterilized (autoclaved for $20 \mathrm{~min}$ at $1 \mathrm{~atm}$ ) nutrient medium Knudson " $C$ " inside of culture flasks (Knudson, 1946). However, this was modified by the addition of coconut water $(100 \mathrm{ml} / \mathrm{L})$ or banana $(100 \mathrm{~g} / \mathrm{L})$, with $3.5 \mathrm{~g}$ of agar (Himédia ${ }^{\circledR}$ ). After 30 days in the culture medium, only 3 species (H. purpurata, $S$. gloriosa and $S$. cernua) were successful. Germinating seeds were maintained in chambers at $26 \pm 3{ }^{\circ} \mathrm{C}$, under $24 \mathrm{~h}$ light (40-W fluorescent lamp) and followed for 105 days.

The seeds of all 6 species and seedlings of the 3 germinated species (as mentioned above) were previously observed under a stereoscopic microscope, fixed in glutaraldehyde ( $1 \%$ in 0.1 M phosphate buffer, pH 7.2, maintained at $4{ }^{\circ} \mathrm{C}$ ) (Karnovsky, 1965) and then preserved in $70 \%$ ethanol. Samples from the seeds and seedlings were dehydrated in ethanol series, embedded in historesin (Guerrits, 1991), sectioned (cross- and longitudinally) in a rotate microtome, and stained with toluidine blue (O’Brien, Feder, \& Maccully, 1965) and toluidine blue/basic fucsin (Junqueira, 1990). Anatomical features were analyzed through optical microscopy using a Leica ICC50 microscope suite, through the Leica LAS EZ software, version 1.8.1.

Specific microchemical tests were carried out for detecting lipids (using Sudan IV and Sudan Black dyes) (Ruzin, 1999), starch (iodine-potassium iodide test), lignin (phloroglucinol test) and cellulose (chloriodide of zinc test) (Berlyn \& Miksche, 1976). Seeds from all 6 studied species were mounted on aluminum stubs, coated with gold, and then examined using a scanning electron microscope (Shimadzu SS-550 Superscan) to obtain digital images.

\section{Results}

All analyzed species presented a minute, fusiform, unitegmic, and exalbuminous seeds (Fig. 1A and D), with an immature ellipsoidal embryo. There is an intercellular space relatively developed between the seed coat and the embryo (Fig. 1D). The translucid and lignified seed coat consists usually of 1 layer of elongated and narrow cells (Fig. 1B) with tapered and sometimes straight ends. The cells of the seed coat show differences concerning their cell wall thickening. All species have thin outer periclinal cell wall, and much thicker anticlinal cell wall (Fig. 1C), the inner periclinal cell wall is thickened in almost all species studied, except in $C$. loddigesii and $H$. purpurata, that have thin-walled inner periclinal cell (Table 1 ).

Table 1

Anatomical features of seed and seedling in studied Laeliinae species. *Species that seed had no germination success.

\begin{tabular}{lllll}
\hline Species & $\begin{array}{l}\text { Inner periclinal cell } \\
\text { wall (seed coat) }\end{array}$ & $\begin{array}{l}\text { Cell-layers of the } \\
\text { suspensor }\end{array}$ & $\begin{array}{l}\text { First leaf of the } \\
\text { protocorm }\end{array}$ & $\begin{array}{l}\text { Vascular system } \\
\text { of the first root }\end{array}$ \\
\hline Cattleya loddigesii & Thin-walled & 2 cells thick & $*$ & $*$ \\
C. tigrina & Thickened & 2 cells thick & $*$ & $*$ \\
Hadrolaelia purpurata & Thin-walled & $2-3$ cells thick & Lanceolate & $*$ \\
Laelia anceps & Thickened & 2 cells thick & Triarch \\
Schomburgkia gloriosa & Thickened & 2 cells thick & Wide pointed sheathlike & $*$ \\
Sophronitis cernua & Thickened & 2 cells thick & Lanceolate & Tetrarch \\
\hline
\end{tabular}



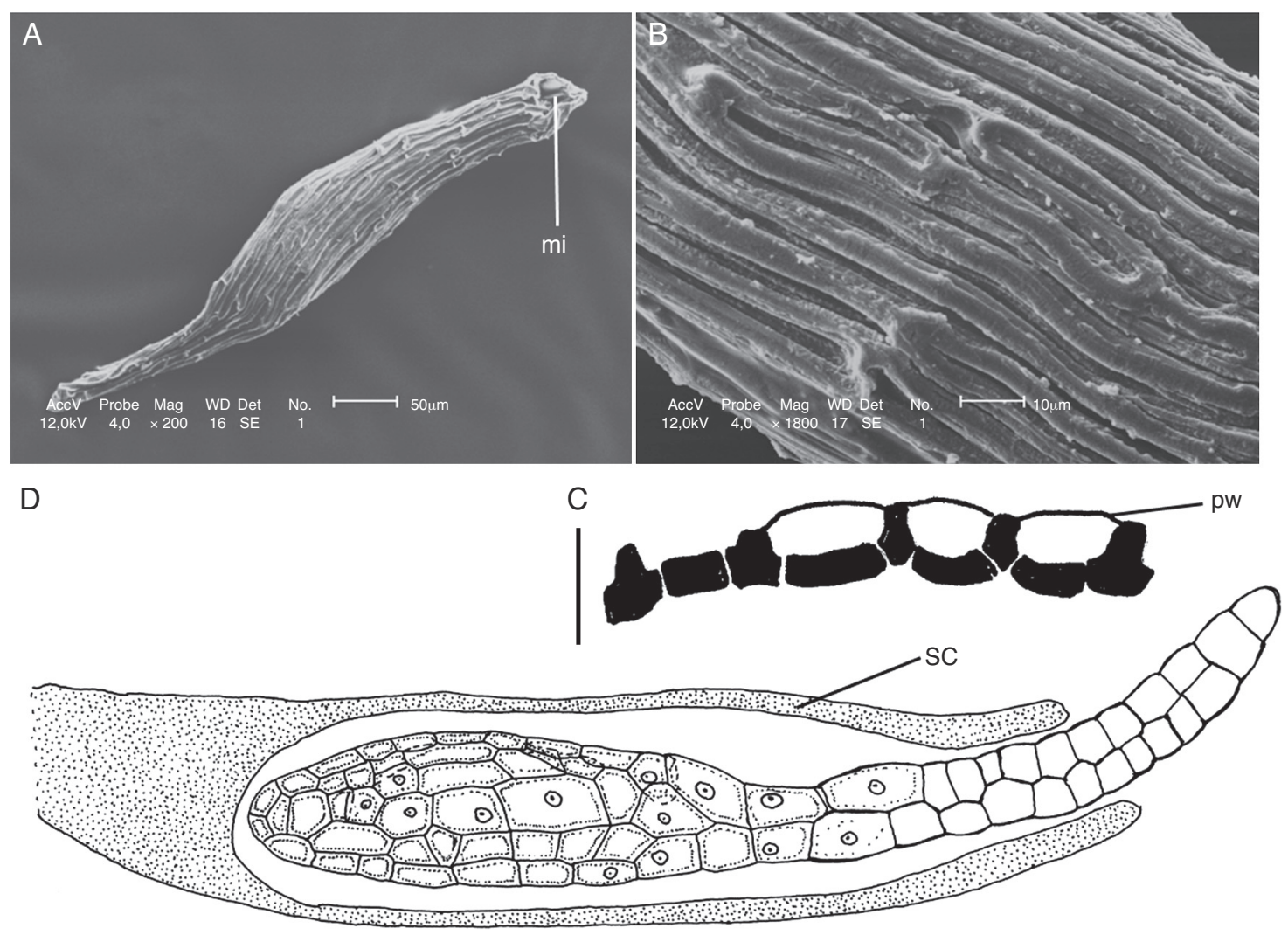

Figure 1. Seeds of Cattleya loddigesii (A-D) and Schomburgkia gloriosa (C). (A, B) Seed and seed coat under scanning electron microscopy (SEM); (C) seed coat in cross-section; (D) seed in longitudinal section showing embryo with suspensor (aw - anticlinal cell wall; iw - inner periclinal cell wall; mi - micropyle; pw outer periclinal cell wall; sc - seed coat). Scale bars: $50 \mu \mathrm{m}$ (A), $10 \mu \mathrm{m}$ (B, C), $80 \mu \mathrm{m}$ (D).

Laeliinae embryos have multicellular and relatively long suspensor, which may extend beyond the micropyle (Fig. 1D). The suspensor consists of 2 cell layers, except in $H$. purpurata that shows $2-3$ cell layers. Embryo cells have low lipids content and no starch.

During the seed germination process, the seed coat cracks allowing the protrusion of a white protocorm, which becomes greenish in a short period of time. The green protocorm is globular (Figs. 2 and 3A) and produces rhizoids in the region which is in contact with the culture medium (Fig. 3B); the small cells in the opposite region undergo cellular division to form the meristematic tissue (Fig. 3A). Such meristematic mass produces a protrusion developing into the first leaf (Figs. $2 \mathrm{~B}$ and $3 \mathrm{C}$ ), and subsequent leaves are produced from this meristem (Fig. 2C-E). The lanceolate leaves (Fig. 2) are thick and have acute apex. The first leaf of $S$. gloriosa (Fig. 2E) is markedly different from that of the other 2 species (H. purpurata and S. cernua); it only has a wide pointed sheath-like leaf that partially covers the protocorm. The taproot has endogenous origin adjacent to the shoot apex on the protocorm; it emerges when seedlings have developed 2-4 leaves. In vitro, some protocorms produce new shoot apices, each one acting as a single seedling (Fig. 2F).

The young protocorm (Fig. 3A) consists of glabrous uniseriate epidermis with stomata, and parenchyma composed of isodiametric cells containing starch. Rhizoids (Fig. 3B) are uni or multicellular. In the shoot apex occur small meristematic cells (Fig. 3A) with large nucleus. Further, the growth of the protocorm reveals the development of the shoot apex (Fig. 3C) with initiation of leaves, differentiation of procambium, and accumulation of starch in the parenchyma. The shoot axis (Fig. 3D and E) has a uniseriate epidermis, a cortex composed by thin-walled parenchyma cells; it lacks a typical endodermis, and shows a single collateral vascular bundle at the central portion.

The structure of the leaves does not differ in essential details, except regarding the vasculature. The epidermis is uniseriate with stomata and the mesophyll is composed of homogeneous parenchyma (Fig. 3D, F, G), which contains idioblasts with raphides. In the first leaf there is just 1 vascular bundle extending from the base to the tip of the leaf (Fig. 3D and G), whereas the subsequent leaves are vascularized by 3 vascular bundles, 1 prominent mid-vein and 2 smaller ones close to the margin of the leaf blade (Fig. 3G).

The taproot has a velamen (Fig. 3H) consisting of 1-3 thick cell-layers, in which the walls are strengthened by anticlinal band-like thickenings. The cortex (Fig. 3H) is made of parenchyma with intercellular spaces, interspersed with raphide cells, and endodermis with Casparian strips. The vascular system is triarch in $H$. purpurata and S. сеrnua (Fig. 3I), and tetrarch in S. gloriosa.

Table 1 summarizes some features of seeds and seedlings that may be potentially significant for species' characterization such as the anatomy of the cell wall in the seed coat, micromorphology of the suspensor, vascular system of the taproot and the external morphology of the first leaf. 

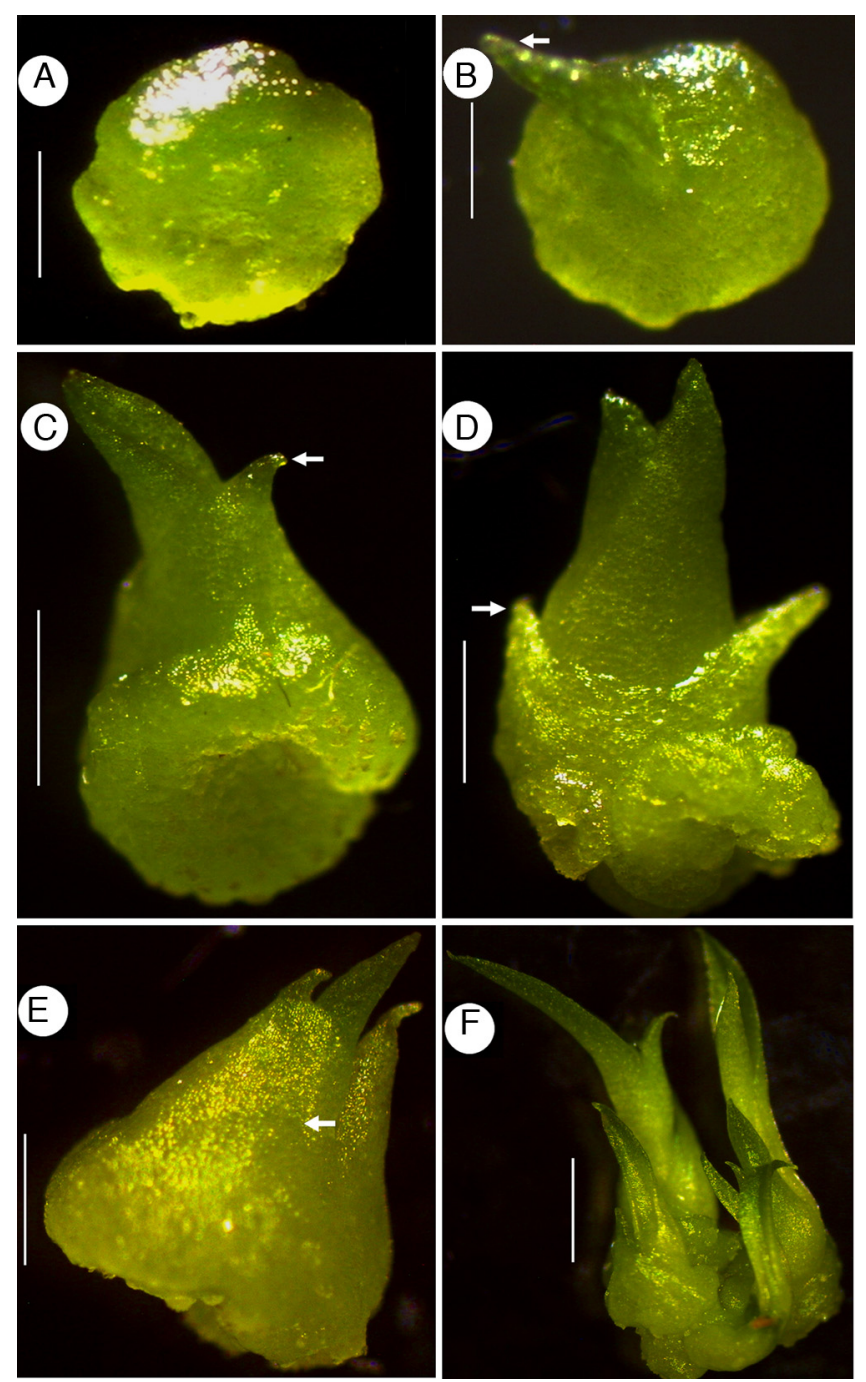

Figure 2. Development of seedlings of Laelia anceps (A, B), Cattleya loddigesii (C, D), Schomburgkia gloriosa (F). (A) Protocorm; (B-D) seedlings with 1, 2 and 4 leaves, respectively; (E) seedling showing sheath-like leaf (white arrow); (F) protocorm with 2 seedlings (white arrow indicates the first leaf). Scale bars: $0.26 \mathrm{~mm}$ (A), $0.32 \mathrm{~mm}$ (B), $1 \mathrm{~mm}(\mathrm{C}, \mathrm{D}), 0.6 \mathrm{~mm}(\mathrm{~F})$.

\section{Discussion}

The seed coat of the studied species consists of only 1 cell layer. In orchids, during seed development both layers of the inner integument and the inner layer of the outer integument degenerate; in the mature seed, the seed coat consists of only 1 layer originated from the outer layer of the outer integument (Barthlott, 1976; Sood \& Rao, 1986). Although the seed coat ontogeny was not assessed, the single layer that compounds the seed coat of the Laeliinae species must have its origin from the external layer of the ovule outer integument, and the other layers (including the inner integument) must have been degenerated during the embryological process, as described for Phalaenopsis amabilis (L.) Blume (Lee, Yeung, Lee, \& Chung, 2008). Most likely, the reduced and membranous seed coat of Laeliinae seeds and the space between the tegument and the embryo is an adaptation related to the aerodynamic properties and to the wettability of seed, which occurs in orchids (Arditti \& Ghani, 2000; Barthlott, 1976; Dahlgren, Clifford, \& Yeo, 1985). Furthermore, Boesewinkel and Bouman (1984) named the orchid seeds as balloon seeds, due to the bladder-like air spaces found inside. Kurzweil (1993) analyzed the seed morphology in more than 150 Southern African Orchidoideae species, and the author found 2 distinct seed types: (1) Satyrium-type, with minute and fusiform seeds (common in the majority of the species in that study), and (2) Disa uniflora-type, with large balloon-like seeds. The mature seed of Laeliinae species analyzed in our study can be classified as Satyrium-type, fusiform seeds.

Embryos of the studied species are similar each other, and show the typical features previously described for orchids in general structure; only the suspensor may undergo some variation. Veyret (1974) recorded some groups of orchids with different suspensors according to species or type; this variation may occur even within the same genus. In the studied species, only $H$. purpurata showed a suspensor with 2-3 cell layers (Table 1) against the usual 2-layers suspensor observed on the rest of the species.

The budding on the protocorm that occurs in Laeliinae seedlings is a common phenomenon in Orchidaceae. Veyret (1974) considered that this phenomenon is able to end up on the formation of multiple seedlings, and are produced with variable frequency according to the species and the medium used for the multiplication.

According to Veyret (1974) 2 situations are presented in orchid's embryos: with or without cotyledons. Cattleya (Laeliinae) is an example of acotyledonous species (Carlson, 1943). However, the first foliaceous organ of orchid's seedling may not be easy to define, for instance, Velenovsky (1907) has referred it as a cotyledon, whereas Carlson (1943) and Veyret (1974) considered it properly as a leaf. Batygina et al. (2003) discussed the term "cotyledon" due to the fact that foliar organs of the majority of orchids appear during the post-seminal development, that is, at the protocorm stage; thus, it would be unsuitable to refer to them as cotyledons or leaf-like organs; the authors have concluded that they are the shoot leaves proper, whereas the embryo itself has no cotyledons. Nevertheless, it is worthy to note that the structural analysis of Laeliinae seedling leaves, in this work, has showed significant differences, which are able to raise the debate concerning the first leaf of the orchid's seedling be considered or not a cotyledon. Two strong arguments can be legitimately used about the cotyledon existence in Laeliinae seedlings: (1) the single vascular strand of first leaf, also referred for cotyledons of epiphytes and monocots species (Boyd, 1932), whereas the other leaves show 3 vascular strands, and (2) the first leaflike organ of $S$. gloriosa, which is a sheath-like structure with a sharp apex that covers partially the protocorm.

The subfamily Epidendroideae, which includes Laeliinae, presents thick aerial roots with multiseriate velamen (Dahlgren et al., 1985), which is an adaptation for epiphytic habit. The first root of the Laeliinae seedlings consists of velamen with 1-3 layers of cells; it has been suggested that velamen possesses the capacity of absorbing and storing water and minerals, avoiding the loss of water (Benzing, Ott, \& Friedman, 1982). The Laeliinae root is triarch or tetrarch which is also similar in structure to Calopogon pulchellus (Carlson, 1943), although 

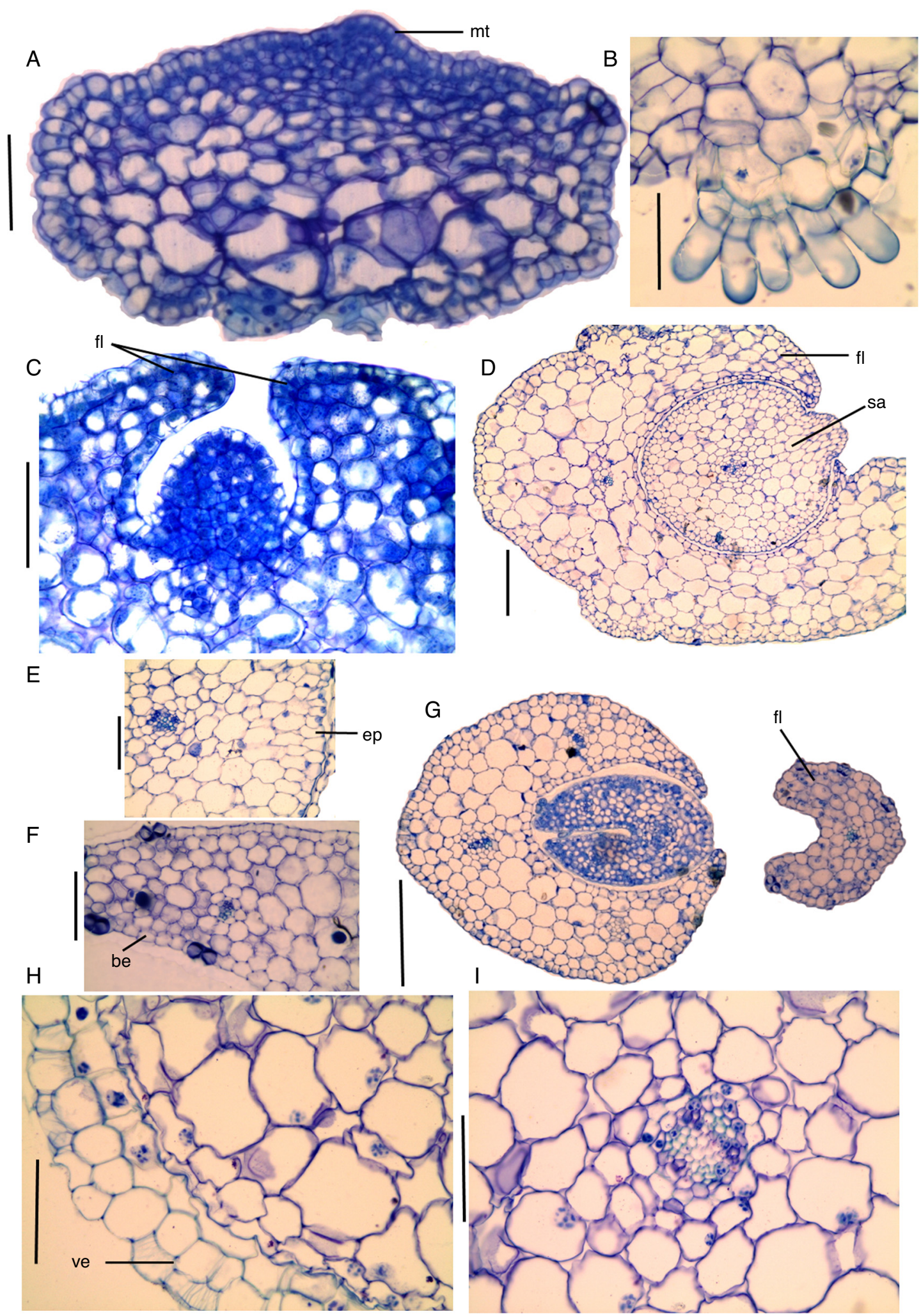

Figure 3. Seedling structure of Sophronitis cernua (A-I), Hadrolaelia purpurata (B) Schomburgkia gloriosa (F, G). (A-C) Protocorms in longitudinal section showing meristematic tissue, rhizoids and the first leaf, respectively; (D) shoot axis and the first leaf in cross-section; (E) detail of shoot axis; (F) longitudinal section of the second leaf; (G) seedling leaves in cross-section; (H) root: detail of the velamen and cortex; I, root: detail of the central cylinder (be - abaxial surface epidermis; co - cortex; ep - epidermis; fl - first leaf; mt - meristematic tissue; sa - shoot axis; ve - velamen). Scale bars: $1 \mathrm{~mm}$ (A), $2 \mathrm{~mm}$ (D), $80 \mu \mathrm{m}$ (B-I). 
in monocots, especially in their adventitious roots, the xylem is usually polyarch (Mauseth, 1988).

The seed and seedling in the Laeliinae species possess some characters, such as the seed coat, suspensor, first leaf in development and the number of protoxylem groups in the root (Table 1), which may be of interest for the taxonomy of the group.

\section{Acknowledgments}

The authors are thankful to Coordenação de Aperfeiçoamento de Pessoal de Nível Superior, Brasil and Conselho Nacional de Desenvolvimento Científico e Tecnológico, Brasil, for financial support to accomplish this study. We are grateful to H. Cota-Sánchez for reviewing the Resumen; to the two anonymous reviewers, to Y. Domínguez and to the Associate editor (L. Rico) for their valuable comments and suggestions for the improvement of the early versions of this manuscript.

\section{References}

Arditti, J., \& Ghani, A. K. A. (2000). Numerical and physical properties of orchid seeds and their biological implications. New Phytologist, 145, 367-421.

Barthlott, W. (1976). Morphologie der Samen von orchi-deen in Hinblick auf taxonomische und functionelle As-pekte. In Proc. 8th World Orchid Conference.

Batygina, T. B., Bragina, E. A., \& Vasileyeva, V. E. (2003). The reproductive system and germination in orchids. Acta Biologica Cracoviensia. Series Botanica, 45, 21-34.

Benzing, D. H., Ott, D. W., \& Friedman, W. E. (1982). Roots of Sobralia macrantha (Orchidaceae): Structure and function of the velamen exodermis complex. American Journal of Botany, 69, 608-614.

Berlyn, G. P., \& Miksche, J. P. (1976). Botanical microtechnique and cytochemistry. Ames: The Iowa State University.

Boesewinkel, F. D., \& Bouman, F. (1984). The seed: structure. In B. M. Johri (Ed.), Embryology of angiosperms (pp. 567-610). Berlin: Springer-Verlag.

Boyd, L. (1932). Monocotyledonous seedlings. Transactions and Proceedings of the Botanical Society of Edinburgh, 31, 5-224.

Carlson, M. C. (1943). The morphology and anatomy of Calopogon pulchellus. Bulletin of the Torrey Botanical Club, 70, 349-368.

Dahlgren, H. T., Clifford, H. T., \& Yeo, P. F. (1985). The families of the monocotyledons: structure, evolution and taxonomy. Berlin: Springer-Verlag.
Dressler, R. L. (1981). The orchids: natural history and classification. Cambridge: Harvard University Press.

Dressler, R. L. (1993). Phylogeny and classification of the orchid family. Portland: Dioscorides Press.

Guerrits, P. O. (1991). The application of glycol methacrylate in histotechnology: some fundamental principles. Groningen: Department of Anatomy and Embryology State University.

Junqueira, C. U. (1990). O uso de cortes finos de tecidos na medicina e biologia. Meios \& Métodos, 66, 10-11.

Karnovsky, M. J. (1965). A formaldehyde-glutaraldehyde fixative of high osmolality for use in electron microscopy. Journal of Cell Biology, 27, 137-138.

Knudson, L. (1946). A new nutrient solution for the germination of orchid seeds. American Orchid Society Bulletin, 15, 214-217.

Kurzweil, H. (1993). Seed morphology in Southern African Orchidoideae (Orchidaceae). Plant Systematics and Evolution, 185, 229-247.

Lee, Y. I., Yeung, E. C., Lee, N., \& Chung, M. (2008). Embryology of Phalaenopsis amabilis var. formosa: embryo development. Botanical Studies, 49, 139-146.

Lista de espécies da Flora do Brasil. (2012). Jardim Botânico do Rio de Janeiro. Retrieved from: http://floradobrasil.jbrj.gov.br/

Mauseth, J. D. (1988). Plant anatomy. California: The Benjamin/Cumings Publishing Company.

O'Brien, T. P., Feder, N., \& Maccully, M. E. (1965). Polychromatic staining of plant cell walls by toluidine blue O. Protoplasma, 59, 368-373.

Ruzin, S. E. (1999). Plant microtechnique and microscopy. New York: Oxford University Press.

Singh, F. (1981). Differential staining of orchid seeds for viability testing. American Orchid Society Bulletin, 50, 416-418.

Sood, S. K., \& Rao, P. R. M. (1986). Studies in the embryology of the diandrous orchid Cypripedium cordigerum (Cypripedieae, Orchidaceae). Plant Systematics and Evolution, 160, 159-168.

Van den Berg, C., Goldman, D. H., Freudenstein, J. V., Pridgeon, A. M., Cameron, K. M., \& Chase, M. W. (2005). An overview of the phylogenetic relationships within Epidendroideae inferred from multiple DNA regions and recircumscription of Epidendreae and Arethuseae (Orchidaceae). American Journal of Botany, 92, 613-624.

Van den Berg, C., Higgins, W. E., Dressler, R. L., Whitten, W. M., Soto-Arenas, M. A., \& Chase, M. A. (2009). A phylogenetic study of Laeliinae (Orchidaceae) based on combined nuclear and plastid DNA sequences. Annals of Botany, 104, 417-430.

Velenovsky, J. (1907). Vergleicheinde morphologie der pflanzen. Part 2. Prague: Fr. Rivinac.

Veyret, Y. (1974). Development of the embryo and the young seedling stages of orchids. In C. L. Withner (Ed.), The orchids (pp. 223-265). New York: John Wiley and Sons. 